\section{Research Reports \\ Modification of Switchgrass Substrate pH Using Compost, Peatmoss, and Elemental Sulfur}

\author{
James E. Altland ${ }^{1,3}$ and Charles Krause ${ }^{2}$
}

AdDITIONAL INDEX WORDs. alternative substrate, potting mix, soilless medium, Panicum virgatum

SuMmary. Switchgrass (Panicum virgatum) biomass is being evaluated as a potential alternative to pine bark as the primary potting component in containerized nursery crops. Substrates composed entirely of switchgrass have higher $\mathrm{pH}$ than what is considered desirable in container substrates. The objective of this research was to evaluate the influence of elemental S, sphagnum moss, and municipal solid waste compost (MSC) as amendments for reducing substrate $\mathrm{pH}$ and buffering it against large changes over time. Three experiments were conducted; the first two experiments were conducted using annual vinca (Catharanthus roseus 'Pacifica Blush') to quickly assess how $\mathrm{pH}$ was affected by the three amendments, and the final experiment was conducted with blueberry (Vaccinium corymbosum 'Duke') to assess the long-term effects of substrate amendments. Summarizing across the three experiments, elemental $\mathrm{S}$ was effective in reducing substrate $\mathrm{pH}$; however, rates $1 \mathrm{lb} / \mathrm{yard}^{3}$ or greater reduced $\mathrm{pH}$ below the recommended level of 5.5 and lower $\mathrm{S}$ rates did not maintain lowered $\mathrm{pH}$ over time. Sphagnum moss and MSC together at $20 \%$ and $10 \%$ $(\mathrm{v} / \mathrm{v})$, respectively, were effective at reducing substrate $\mathrm{pH}$ and buffering against change. Sphagnum moss and MSC provided the additional benefit of improving physical properties of the switchgrass substrates.

S witchgrass is a perennial grass currently being developed for its biofuel potential. Our laboratory has been exploring the possibility of using switchgrass as a raw

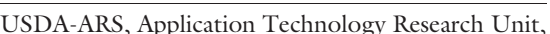
Ohio Agricultural Research and Development Center, 1680 Madison Ave., Wooster, OH 44691

Mention of proprietary products or company is included for the reader's convenience and does not imply any endorsement or preferential treatment by USDA/ARS.

This research was funded primarily by the Floriculture and Nursery Research Initiative.

${ }^{1}$ Research Horticulturist

${ }^{2}$ Research Leader and Plant Pathologist

${ }^{3}$ Corresponding author. E-mail: James.Altland@ars.usda. gov.

50 material for nursery container substrates. Baled switchgrass processed through a hammer mill can be modified such that it makes a suitable nursery substrate for short-production cycle crops (Altland and Krause, 2009). One of the problems with switchgrass and other grass-based substrates is that $\mathrm{pH}$ of these ground materials is 7 to 7.5 , higher than what is typically recommended for nursery crop production (4.5 to 6.5) (Yeager et al., 2007). Substrate $\mathrm{pH}$ could be lowered in switchgrass substrates by amending with other physical components that have lower $\mathrm{pH}$ (e.g., sphagnum moss). It is also possible that the addition of organic substrates with high cation exchange capacity, in the form of compost, might reduce and buffer substrate $\mathrm{pH}$ over time.

Chemical amendments can also be used to lower $\mathrm{pH}$ of soils and substrates. Elemental $S$ has been used to lower $\mathrm{pH}$ in field soils and container substrates. Bishko and Fisher (2003) demonstrated that flowable elemental $S$ reduced a peat-based medium by $3.3 \mathrm{pH}$ units over the course of $28 \mathrm{~d}$. Rathier (1983) demonstrated that flowable elemental $S$ applications up to $2400 \mathrm{lb} /$ acre $\left(2.2 \mathrm{lb} / \mathrm{yard}^{3}\right)$ reduced substrate $\mathrm{pH}$ by more than 3 units in a compost and peat substrate and caused no injury to container-grown 'Rosebud' azaleas (Rhododendron sp.). Giblin and Gillman (2006) showed that various formulations of elemental $S$ incorporated into the substrate reduced $\mathrm{pH}$ by $\mathrm{l}-2$ units below non-amended controls over a duration of $84 \mathrm{~d}$ while having no adverse effect on blueberry (Vaccinium $\times$ 'Northcountry') growth in a peat and pine bark substrate.

The objective of this research was to determine the effect of sphagnum moss, municipal solid waste compost (MSC), and elemental S on $\mathrm{pH}$ of substrates composed primarily of switchgrass and subsequent plant growth. Our approach was to initially use a short-production cycle annual crop to determine the immediate impacts of the aforementioned amendments, followed

\begin{tabular}{llll}
\hline $\begin{array}{l}\text { Units } \\
\text { To convert U.S. to SI, } \\
\text { multiply by }\end{array}$ & U.S. unit & SI unit & $\begin{array}{l}\text { To convert SI to U.S., } \\
\text { multiply by }\end{array}$ \\
\hline 0.7457 & horsepower & $\mathrm{kJ} \cdot \mathrm{s}^{-1}$ & 1.3410 \\
2.54 & inch $(\mathrm{es})$ & $\mathrm{cm}$ & 0.3937 \\
25.4 & inch $(\mathrm{es})$ & $\mathrm{mm}$ & 0.0394 \\
1.1209 & $\mathrm{lb} / \mathrm{acre}$ & $\mathrm{kg} \cdot \mathrm{ha}^{-1}$ & 0.8922 \\
0.5933 & $\mathrm{lb} / \mathrm{yard}^{3}$ & $\mathrm{~kg} \cdot \mathrm{m}^{-3}$ & 1.6856 \\
28.3495 & $\mathrm{oz}$ & $\mathrm{g}$ & 0.0353 \\
1.7300 & $\mathrm{oz} / \mathrm{inch}^{3}$ & $\mathrm{~g} \cdot \mathrm{cm}^{-3}$ & 0.5780 \\
1 & $\mathrm{ppm}$ & $\mathrm{mg} \cdot \mathrm{kg}^{-1}$ & 1 \\
$\left({ }^{\circ} \mathrm{F}-32\right) \div 1.8$ & ${ }^{\circ} \mathrm{F}$ & ${ }^{\circ} \mathrm{C}$ & $\left(1.8 \times{ }^{\circ} \mathrm{C}\right)+32$ \\
& & &
\end{tabular}

Hortlechnology · December 2010 20(6) 
by a long-term woody crop to document long-term effects on $\mathrm{pH}, \mathrm{pH}$ buffering, and plant growth.

\section{Materials and methods}

Switchgrass was cut and baled early Spring 2009 on a farm in
Meadeville, PA, and stored in a barn until needed. One day before starting each experiment, materials were processed through a 15-horsepower hammer mill (C.S. Bell, Tiffin, OH) equipped with a 0.188 -inch screen. MSC was obtained from the Lake

Table 1. Physical properties of substrates composed of switchgrass after being processed through a hammer mill with 0.188 -inch $(4.7752-\mathrm{mm})$ screen and amended with $0 \%$ or $10 \%$ municipal solid waste compost (MSC), and $0 \%$ or $20 \%$ sphagnum moss $(\mathbf{n}=3)$.

\begin{tabular}{|c|c|c|c|c|c|}
\hline MSC (\%) & $\begin{array}{c}\text { Peatmoss } \\
(\%)\end{array}$ & $\begin{array}{c}\text { Air space } \\
(\%)\end{array}$ & $\begin{array}{c}\text { Container } \\
\text { capacity (\%) }\end{array}$ & $\begin{array}{c}\text { Total } \\
\text { porosity }(\%)\end{array}$ & $\begin{array}{l}\text { Bulk density } \\
\quad\left(\mathrm{g} \cdot \mathrm{cm}^{-3}\right)^{\mathrm{z}}\end{array}$ \\
\hline \multirow[t]{2}{*}{0} & 0 & 55 & 37 & 92 & 0.07 \\
\hline & 20 & 48 & 42 & 90 & 0.06 \\
\hline \multirow[t]{2}{*}{10} & 0 & 46 & 46 & 92 & 0.08 \\
\hline & 20 & 42 & 47 & 89 & 0.08 \\
\hline $\operatorname{LSD}_{0.05^{y}}$ & & 2 & 3 & 2 & 0.003 \\
\hline \multicolumn{6}{|l|}{ Main effects } \\
\hline MSC & & 0.0001 & 0.0001 & 0.2066 & 0.0001 \\
\hline Peatmoss & & 0.0001 & 0.0080 & 0.0030 & 0.0005 \\
\hline Interaction & & 0.0393 & 0.0330 & 0.3585 & 0.5837 \\
\hline
\end{tabular}

${ }^{\mathrm{z}} 1 \mathrm{~g} \cdot \mathrm{cm}^{-3}=0.5780 \mathrm{oz} /$ inch $^{3}$.

${ }^{y}$ Fisher's least significant difference (LSD) test within a column $(\alpha=0.05)$.

County Department of Utilities, Painesville, $\mathrm{OH}$, and was commonly used in the Ohio nursery industry.

Expт. 1. Treatment design was a two by two by three factorial, with $0 \%$ or $10 \%$ MSC, $0 \%$ or $20 \%$ sphagnum moss (Conrad Fafard, Agawam, $\mathrm{MA}$ ), and either 0,1 , or $4 \mathrm{lb} /$ yard $^{3}$ elemental S (Yellow Jacket Wettable Dusting Sulfur; Georgia Sulfur, Valdosta, GA). All substrates were amended with $1.5 \mathrm{lb} /$ yard $^{3}$ Micro$\max$ (Scotts, Marysville, $\mathrm{OH}$ ) micronutrients and $2 \mathrm{lb} /$ yard $^{3}$ gypsum. All aforementioned amendments were incorporated into the substrate by hand-mixing in a plastic container. Substrates were filled in containers 6 inches tall and wide and potted with a single 'Pacifica Blush' vinca on 13 Mar. 2009. Vinca were germinated and grown in 50-cell flats. Vinca were 5 to $6 \mathrm{~cm}$ tall, 10 to $12 \mathrm{~cm}$ wide, and not flowering at the time of potting. All containers were topdressed with $16 \mathrm{~g} 18 \mathrm{~N}-2.6 \mathrm{P}-10 \mathrm{~K}$ controlledrelease fertilizer (Osmocote 18-6-12 Classic, 8 to 9 -month release; Scotts).

Table 2. Substrate pH, chlorophyll content, and shoot dry weight (SDW) of annual vinca grown in substrates composed of switchgrass hammer milled with a 0.188 -inch $(4.7752 \mathrm{~mm})$ screen and amended with $0 \%$ or $10 \%$ municipal solid waste compost (MSC), $0 \%$ or $20 \%$ sphagnum moss, and 0,1 , or $4 \mathrm{lb} / \mathrm{yard}^{3}\left(0,0.6\right.$, or $2.4 \mathrm{~kg} \cdot \mathrm{m}^{-3}$, respectively) elemental S.

\begin{tabular}{|c|c|c|c|c|c|c|c|}
\hline \multirow[b]{2}{*}{ MSC (\%) } & \multirow{2}{*}{$\begin{array}{c}\text { Peatmoss } \\
(\%)\end{array}$} & \multirow{2}{*}{$\begin{array}{c}S \\
\left(1 \mathrm{~b} / \text { yard }^{3}\right)\end{array}$} & \multicolumn{3}{|c|}{ Substrate $\mathrm{pH}$} & \multirow{2}{*}{$\begin{array}{c}\text { Chlorophyll } \\
\text { content }^{\mathrm{y}} \text { at } 6 \mathrm{WAP}\end{array}$} & \multirow{2}{*}{$\begin{array}{c}\text { SDW at } \\
6 \text { WAP }(g)^{x} \\
\end{array}$} \\
\hline & & & $1 \mathrm{WAP}^{\mathrm{z}}$ & 4 WAP & $6 \mathrm{WAP}$ & & \\
\hline \multirow[t]{4}{*}{0} & 0 & 0 & 7.7 & 7.7 & 7.5 & 46.7 & 2.4 \\
\hline & & 4 & 5.6 & 2.9 & 2.6 & 32.1 & 1.7 \\
\hline & 20 & 0 & 5.3 & 6.0 & 6.0 & 59.8 & 4.0 \\
\hline & & 1 & 3.6 & 3.0 & 2.6 & 22.9 & 2.2 \\
\hline \multirow[t]{5}{*}{10} & 0 & 0 & 6.1 & 6.5 & 6.9 & 54.5 & 3.7 \\
\hline & & 1 & 4.8 & 4.8 & 5.0 & 47.6 & 3.0 \\
\hline & & 4 & 3.3 & 3.1 & 2.9 & 29.7 & 1.2 \\
\hline & 20 & 0 & 5.5 & 5.6 & 5.7 & 58.3 & 5.1 \\
\hline & & 1 & 4.1 & 4.2 & 4.2 & 46.7 & 2.9 \\
\hline \multicolumn{8}{|c|}{ Main effects } \\
\hline $\operatorname{MSC}(\mathrm{C})$ & & & 0.0001 & 0.7814 & 0.0055 & 0.0030 & 0.0027 \\
\hline Peat (P) & & & 0.0001 & 0.0001 & 0.0001 & 0.1354 & 0.0001 \\
\hline $\mathrm{C} \times \mathrm{P}$ & & & 0.0001 & 0.0113 & 0.3364 & 0.3970 & 0.5482 \\
\hline$S$ & & & 0.0001 & 0.0001 & 0.0001 & 0.0001 & 0.0001 \\
\hline $\mathrm{S} \times \mathrm{C}$ & & & 0.0001 & 0.0001 & 0.0001 & 0.0045 & 0.0001 \\
\hline $\mathrm{S} \times \mathrm{P}$ & & & 0.0001 & 0.0001 & 0.0001 & 0.0006 & 0.0001 \\
\hline $\mathrm{S} \times \mathrm{P} \times \mathrm{C}$ & & & 0.0001 & 0.0001 & 0.0001 & 0.0379 & 0.6004 \\
\hline
\end{tabular}

${ }^{2}$ Weeks after potting.

yChlorophyll content measured with a chlorophyll meter (SPAD-502; Minolta, Ramsey, NJ).

${ }^{\mathrm{x}} \mathrm{lg}=0.0353 \mathrm{oz}$.

"Fisher's least significant difference (LSD) test within a column $(\alpha=0.05)$. 
Containers were checked daily by weighing and overhead irrigated with 0.25 inch of water when substrates were dry. Vinca were grown in a heated polyethylene-covered hoop house with heat and cool set points at 74 and $80{ }^{\circ} \mathrm{F}$, respectively. Light was supplemented with sodium vapor lights from 0600 to $2000 \mathrm{HR}$.

A sample of each substrate was set aside at the time of potting to determine physical properties. Substrates were packed in $\mathrm{Al}$ cores (3 inches tall by 3 inches i.d.) according to methods described by Fonteno and Bilderback (1993). There were three replications for each substrate. Aluminum cores were attached to substrate porometers for determination of air space (AS). Cores were weighed, oven dried for $4 \mathrm{~d}$ at $72^{\circ} \mathrm{C}$, and weighed again to determine container capacity (CC). Total porosity was calculated as the sum of AS and CC. Bulk density was determined using oven-dried substrate in $\mathrm{Al}$ cores.

Substrate $\mathrm{pH}$ was measured using the pour-through procedure at 1,4 , and 6 weeks after potting (WAP). Ten leaves of recently matured foliage were harvested (Mills and Jones, 1996) 6 WAP, rinsed with deionized water, and then oven dried at $72{ }^{\circ} \mathrm{C}$ for $3 \mathrm{~d}$. Samples were ground in a Cyclotec mill (Tecator AB, Hogenas, Sweden) through a $0.5-\mathrm{mm}$ screen. Foliar N was measured with a carbon and nitrogen analyzer (Vario Max; Elementar Americas, Mt Laurel, NJ). Other macronutrients and micronutrients were measured with an inductively coupled plasma optical emission spectrometer (Iris Intrepid; Thermo Fisher Scientific, Waltham, MA). Foliar chlorophyll content was measured with a chlorophyll meter (SPAD-502; Minolta, Ramsey, NJ) 6 WAP, by averaging five readings per single plant replication. Shoot dry weight (SDW) was measured 6 WAP by harvesting all shoot tissue and drying in an oven at $72{ }^{\circ} \mathrm{C}$ for $3 \mathrm{~d}$. There were five single-plant replications per treatment combination arranged in a completely randomized design.

ExPT. 2. This experiment was conducted similar to Expt. 1, with the following exceptions. All substrates were amended with 10\% MSC. Elemental $S$ was applied at 0 , 0.25 , or $0.5 \mathrm{lb} /$ yard $^{3}$. Vinca were potted on 27 Apr. 2009 and averaged $6 \mathrm{~cm}$ tall and $12 \mathrm{~cm}$ wide at the time of potting. Data collected included substrate $\mathrm{pH}$ and SPAD chlorophyll readings taken 2, 4, and 7 WAP; foliar nutrient content of plant foliage measured $7 \mathrm{WAP}$; and SDW at $7 \mathrm{WAP}$.

ЕхРт. 3. 'Duke' blueberries from 50 -cell packs were potted into one of four substrates composed of pine bark, or switchgrass amended with $0,0.25$, or $0.5 \mathrm{lb} / \mathrm{yard}^{3} \mathrm{~S}$. Blueberries were $\approx 8 \mathrm{~cm}$ tall and 15 $\mathrm{cm}$ wide at the time of potting. All substrates were amended with $20 \%$ sphagnum moss (v/v), 10\% MSC (v/ v), $1.5 \mathrm{lb} /$ yard $^{3}$ Micromax micronutrients, and $2 \mathrm{lb} /$ yard $^{3}$ gypsum by incorporation. Containers were topdressed with $20 \mathrm{~g}$ of Osmocote 18 6-12 Classic controlled-release fertilizer. Containers were grown outside on a gravel pad and irrigated overhead with 0.5 inches of water daily if needed. There were 12 single-pot replications per treatment at the start of the trial, arranged in a completely randomized design. Substrate $\mathrm{pH}$ was measured $1,4,12$, and 20 WAP with the pour-through method, and SPAD chlorophyll content was measured 12 and $20 \mathrm{WAP}$. At $12 \mathrm{WAP}$, half of the replications in each treatment were randomly selected and destructively harvested to measure foliar nutrient content and SDW and record root ratings. Root ratings were assigned on a scale from 0 to 10 as an estimate of the percent of the substrate-container interface covered by roots, where $0=$ no roots visible and $10=$ complete coverage by root mass.

Data from all experiments were subjected to analysis of variance (ANOVA) with means separation by Fisher's protected least significant difference test $(\alpha=0.05)$. Repeatedmeasures ANOVA was used when the same data were collected more than once over time. Regression analysis was used to relate vinca SPAD and SDW to substrate $\mathrm{pH}$ in Expt. 1.
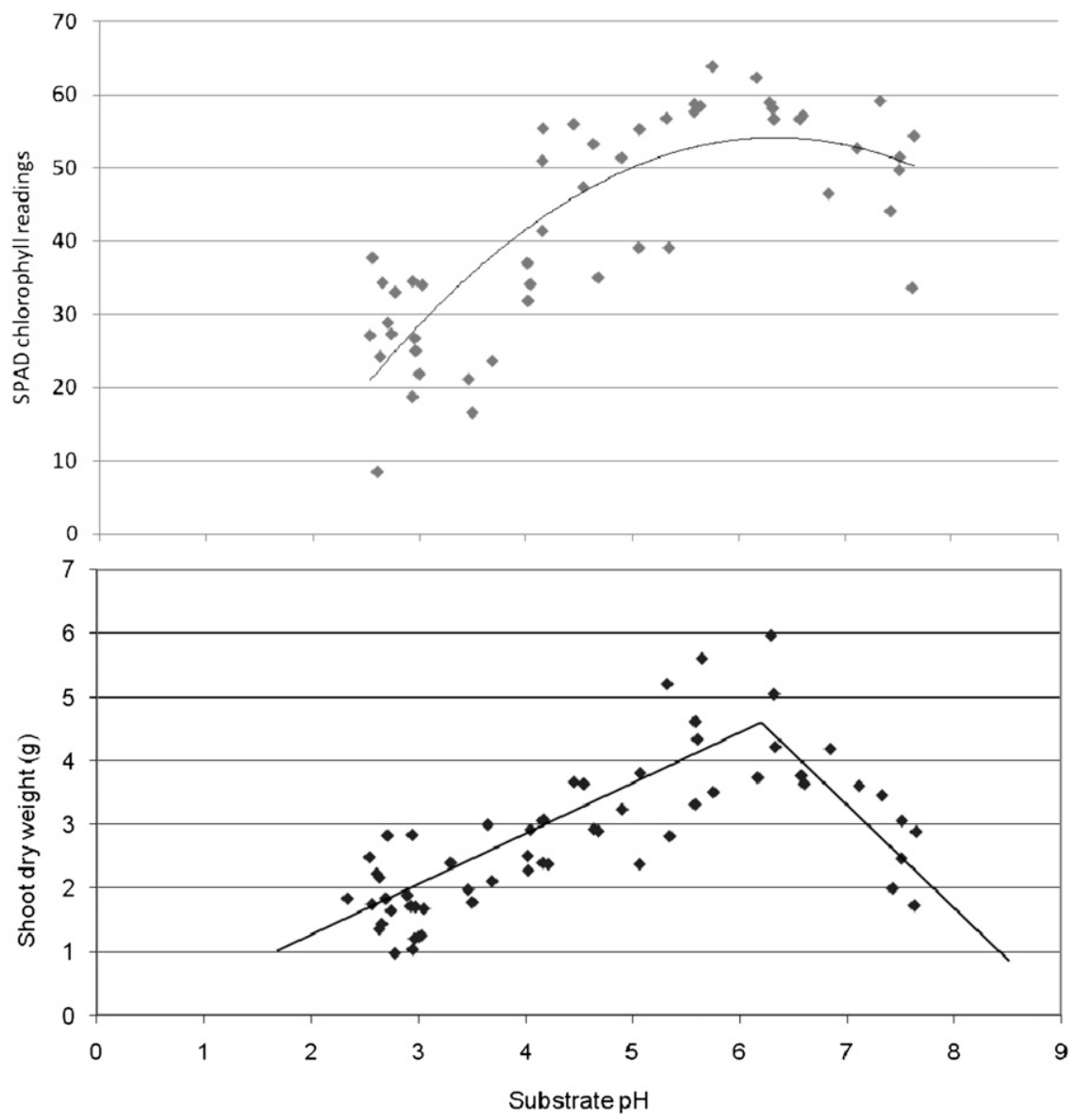

Fig. 1. Relationship between substrate $\mathrm{pH}$ and chlorophyll meter readings (SPAD502; Minolta, Ramsey, NJ) or shoot dry weight (SDW) of 'Pacifica Blush' annual vinca grown in switchgrass substrates; $\mathrm{SPAD}=-2.29 \times \mathrm{pH}^{2}+29.10 \times \mathrm{pH}-$ $38.09, R^{2}=0.6578 ; \mathrm{SDW}=0.82 \times \mathrm{pH}-0.55$ over the $\mathrm{pH}$ range 2.3 to $6.3 ; \mathrm{SDW}=$ $-1.65 \times \mathrm{pH}+15.60$ over the $\mathrm{pH}$ range 6.3 to $7.6, R^{2}=0.7031 ; 1 \mathrm{~g}=0.0353 \mathrm{oz}$. 


\section{Results and discussion}

ExPT. 1. Adding MSC and peatmoss affected substrate physical properties (Table 1). Ideal ranges for physical properties are $10 \%$ to $30 \%$ AS and $45 \%$ to $65 \%$ CC (Yeager et al., 2007). Substrates not amended with either MSC or peatmoss had high AS and low $C C$ relative to ideal ranges. Adding 10\% compost reduced AS and increased CC by $9 \%$. Adding 20\% peatmoss decreased AS by 7\% and increased $\mathrm{CC}$ by $5 \%$. Substrates amended with MSC, with or without peatmoss, had CC within the ideal range, but still had high AS. High AS has been associated with reduced root diseases in container substrates (Ownley et al., 1990). Differences in bulk density were minor. Across all substrates, bulk density averaged $0.07 \mathrm{~g} \cdot \mathrm{cm}^{-3}$, which is slightly less than bulk density of sphagnum moss $\left(\approx 0.09 \mathrm{~g} \cdot \mathrm{cm}^{-3}\right)$ and less than half the bulk density of pine bark $(\approx 1.8$ $\left.\mathrm{g} \cdot \mathrm{cm}^{-3}\right)$.

Repeated-measures analysis showed $\mathrm{pH}$ changed over time with significant time by treatment interactions $(P=0.0221)$. Substrate $\mathrm{pH}$ was 7.7 and declined slightly over time to 7.5 for substrates not amended with MSC, peatmoss, or S (Table 2). Substrates not amended with MSC or peatmoss but amended with 1 or $4 \mathrm{lb} /$ yard $^{3} \mathrm{~S}$ decreased by more than $2 \mathrm{pH}$ units from 1 to 4 WAP. Rathier (1983) reported that flowable elemental $S$ applied as a drench application at rates of 1600 and $2400 \mathrm{lb} /$ acre $(\approx 1.5$ and $2.25 \mathrm{lb} /$ yard $^{3} \mathrm{~S}$, respectively) reduced $\mathrm{pH}$ of a 2 hardwood bark : 1 sand : 1 peatmoss substrate by 2.1 and $2.4 \mathrm{pH}$ units, respectively, after $77 \mathrm{~d}$. Amendment with both peatmoss and MSC resulted in greater $\mathrm{pH}$ buffering than either component alone, with changes of 0.1 to $0.3 \mathrm{pH}$ units over the course of the experiment. The combination of peatmoss and MSC reduced $\mathrm{pH}$ more than either component alone at 4 and 6 WAP. It is possible that the combination of peatmoss and MSC was most effective in buffering $\mathrm{pH}$ because of an additive effect from their chemical properties, or because addition of both components reduced the percent volume of switchgrass lower than either component alone. Amendment with $S$ at either 1 or $4 \mathrm{lb} /$ yard $^{3}$ reduced $\mathrm{pH}$ to below 5.5 , the minimum of the range

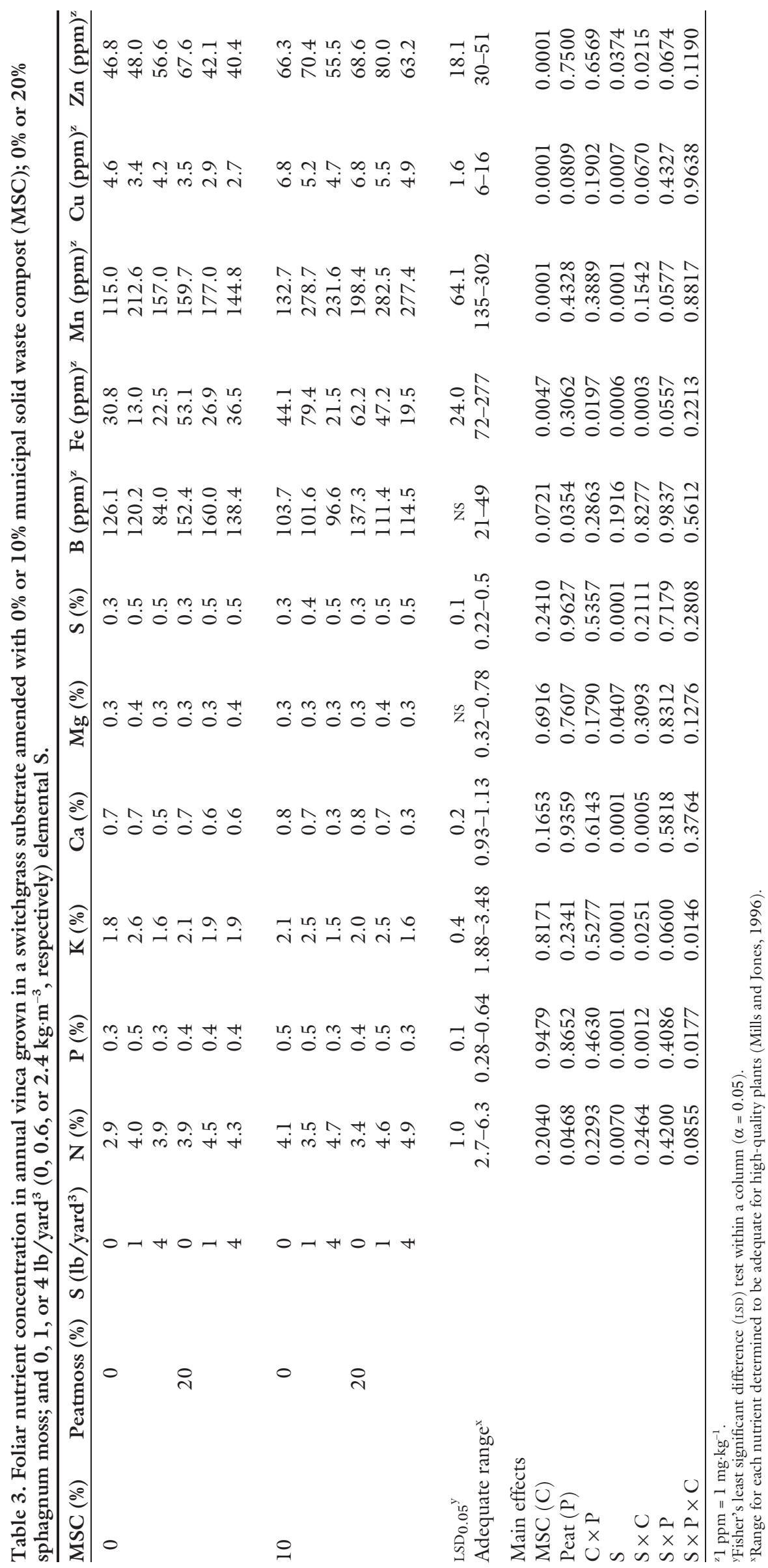

953 
considered optimum for annual vinca (Kessler, 1998).

SPAD chlorophyll content was affected by an interaction between MSC, peatmoss, and $S$ rate (Table 2 ). Chlorophyll content decreased with increasing $S$ rate within each of the four MSC and peatmoss substrate combinations, although the amount of decrease varied with each substrate type. There was a quadratic relationship between substrate $\mathrm{pH}$ and chlorophyll readings at 6 WAP (Fig. 1). Maximum chlorophyll content occurred at $\mathrm{pH}$ 6.3, a level provided most closely by amendment with MSC, peatmoss, or both, and exclusion of S. Chlorophyll content is often correlated to $\mathrm{N}$ content, in particular with annual vinca (Altland et al.,
2002). Foliar $\mathrm{N}$ increased with addition of $S$ in this study (Table 3 ) and is thus not likely the cause of the observed chlorosis. Furthermore, all vinca had adequate foliar $\mathrm{N}$ levels (Mills and Jones, 1996). Foliar K, Ca, Fe, and Cu were affected by amendments and were below the adequate range, whereas all other measured nutrients were within or above the adequate range. Foliar $\mathrm{K}$ and $\mathrm{Ca}$ dropped below the adequate range only in substrates amended with $4 \mathrm{lb} / \operatorname{yard}^{3} \mathrm{~S}$. High $\mathrm{S}$ rates would result in elevated $\mathrm{H}^{+}$concentrations in the substrate, displacing $\mathrm{K}$ and $\mathrm{Ca}$ cations from exchange sites in the substrate. Foliar Fe and $\mathrm{Cu}$ levels were affected by MSC and S amendments. MSC increased foliar Fe and $\mathrm{Cu}$, whereas $\mathrm{S}$ had variable effect on both nutrients depending on substrate type. No single nutrient deficiency or toxicity explains the observed chlorosis. Instead, it was likely a combination of nutritional factors related to low or high $\mathrm{pH}$.

Shoot dry weight was greatest for plants growing in substrate amended with MSC and peatmoss but without $S$ (Table 2). Addition of 1 or $4 \mathrm{lb} /$ yard $^{3}$ $S$ decreased SDW of annual vinca in all substrates except $100 \%$ switchgrass. Similar to chlorophyll content, SDW was correlated to substrate $\mathrm{pH}$ but instead fit with a two-segment linear regression model. Maximum SDW, as indicated by the break point in the piecewise regression analysis, occurred when substrate $\mathrm{pH}$ was 6.3 . This value is the same $\mathrm{pH}$ that maximized foliar

Table 4. Substrate $\mathrm{pH}$, foliar chlorophyll content, and shoot dry weight (SDW) of annual vinca growing in switchgrass substrates amended with $0 \%$ or $20 \%$ sphagnum moss and $0,0.25$, or $0.5 \mathrm{lb} /$ yard $^{3}\left(0,0.148\right.$, or $0.297 \mathrm{~kg} \cdot \mathrm{m}^{-3}$, respectively) elemental S.

\begin{tabular}{|c|c|c|c|c|c|c|c|c|}
\hline \multirow[b]{2}{*}{ Peatmoss (\%) } & \multirow[b]{2}{*}{$S\left(1 b /\right.$ yard $\left.^{3}\right)$} & \multicolumn{3}{|c|}{ Substrate $\mathrm{pH}$} & \multicolumn{3}{|c|}{ Chlorophyll content $\mathrm{t}^{\mathrm{y}}$} & \multirow{2}{*}{$\begin{array}{c}\text { SDW at } \\
7 \text { WAP }(\mathbf{g})^{x}\end{array}$} \\
\hline & & $2 \mathrm{WAP}^{\mathrm{z}}$ & 4 WAP & $7 \mathrm{WAP}$ & $2 \mathrm{WAP}$ & $4 \mathrm{WAP}$ & $7 \mathrm{WAP}$ & \\
\hline \multirow[t]{2}{*}{0} & 0 & 6.2 & 6.3 & 6.5 & 60.4 & 50.3 & 52.3 & 6.9 \\
\hline & 0.5 & 4.5 & 5.4 & 5.8 & 57.2 & 48.8 & 52.7 & 7.9 \\
\hline 20 & 0 & 4.7 & 5.4 & 5.7 & 57.5 & 48.3 & 54.8 & 8.4 \\
\hline $\mathrm{LSD}_{0.05}{ }^{\mathrm{w}}$ & & 0.1 & 0.2 & 0.6 & 2.8 & 4.1 & NS & 1.3 \\
\hline \multicolumn{9}{|l|}{ Main effects } \\
\hline Peat & & 0.0001 & 0.0001 & 0.0001 & 0.0087 & 0.3436 & 0.5624 & 0.0002 \\
\hline
\end{tabular}

${ }^{\mathrm{z}}$ Weeks after potting.

${ }^{y}$ Chlorophyll content measured with a chlorophyll meter (SPAD-502; Minolta, Ramsey, NJ).

${ }^{x} 1 \mathrm{~g}=0.0353 \mathrm{oz}$.

"Fisher's least significant difference (LSD) test within a column $(\alpha=0.05)$.

Table 5. Substrate pH, chlorophyll content, shoot dry weight (SDW), and root ratings of blueberry growing in pine bark and switchgrass substrates amended with $0,0.25$, or $0.5 \mathrm{lb} / \mathrm{yard}^{3}\left(0,0.148\right.$, or $0.297 \mathrm{~kg} \cdot \mathrm{m}^{-3}$, respectively) elemental S.

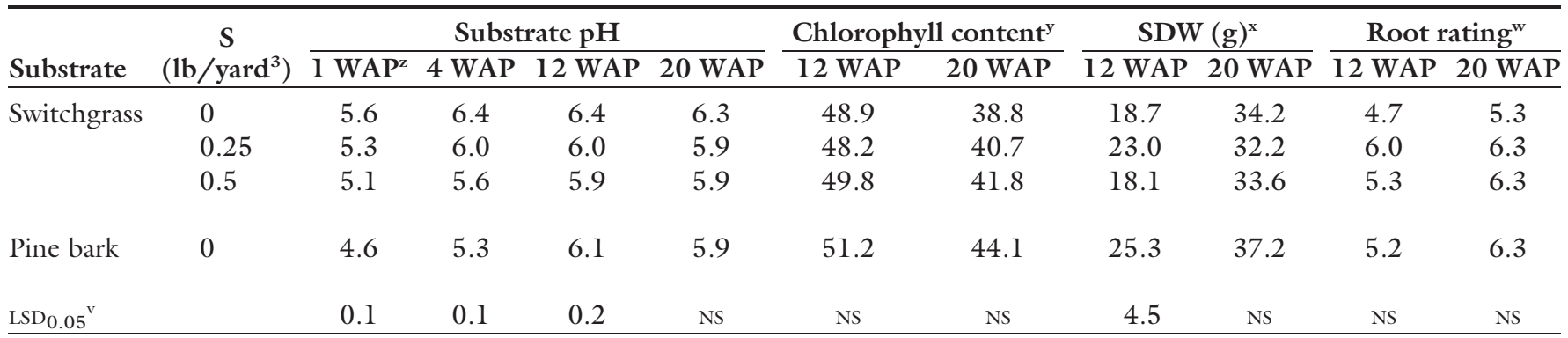

${ }^{2}$ Weeks after potting.

y Chlorophyll content measured with a chlorophyll meter (SPAD-502; Minolta, Ramsey, NJ).

${ }^{\mathrm{x}} \mathrm{lg}=0.0353 \mathrm{oz}$.

whoot ratings estimate the percentage of substrate-container interface covered by roots and are on a scale from 0 to 10 , where $0=$ no roots visible and $10=$ complete coverage of the substrate-container interface.

'Fisher's least significant difference (LSD) test within a column $(\alpha=0.05)$. 
SPAD readings. SDW increased with increasing $\mathrm{pH}$ from 2.3 to 6.3 and then decreased with increasing $\mathrm{pH}$ from 6.3 to 7.6 .

EXPт. 2. The experiment was repeated with lower $S$ rates and with all substrates amended with MSC to reduce treatment numbers. Repeatedmeasures analysis indicated a significant time by peatmoss by $S$ interaction $(P=0.0001)$. Substrates amended with peatmoss were more buffered against change in $\mathrm{pH}$ than those not amended. At $2 \mathrm{WAP}$, difference in $\mathrm{pH}$ of substrates amended with peatmoss and $0.5 \mathrm{lb} /$ yard $^{3} \mathrm{~S}$ was $0.9 \mathrm{pH}$ units lower than those with peatmoss but without S (Table 4). In contrast, substrates lacking peatmoss were reduced by $1.7 \mathrm{pH}$ units when comparing the 0 and $0.5 \mathrm{lb} /$ yard $^{3} S$ rates. Among containers amended with peatmoss, those amended with $S$ were below the recommended $\mathrm{pH}$ range of 5.5 to 6.5 for annual vinca (Kessler, 1998).

Foliar SPAD readings were high among all treatments throughout the experiment (Table 4). There were differences in SPAD readings 2 and 4 WAP, although these differences were minor. By 7 WAP, there were no differences in foliar SPAD readings among substrate or $S$ treatments and all readings were high $(>50)$ relative to well-fertilized vinca in other research (Altland et al., 2002). Foliar nutrient concentrations were largely unaffected by peatmoss or $\mathrm{S}$ rate. Only foliar $\mathrm{Ca}$, $\mathrm{Mn}, \mathrm{Cu}$, and $\mathrm{Zn}$ differed among treatments, and these differences were all minor (data not shown).

Vinca SDW was affected by peatmoss and $S$ rate, but not by their interaction (Table 4). Across peatmoss rates, the largest vinca were those receiving the highest $S$ rate (contrast analysis, $P=0.0075$, data not shown). Across $S$ rates, substrates amended with peatmoss were larger than those not amended (contrast analysis, $P=0.0002$, data not shown).

Expт. 3. At 1 WAP, substrate $\mathrm{pH}$ in switchgrass substrates decreased with increasing $S$ rate (Table 5). Substrate $\mathrm{pH}$ of pine bark substrates was lower than all switchgrass substrates. This trend continued until 12 WAP, when pine bark and switchgrass substrates amended with either 0.25 or $0.5 \mathrm{lb} /$ yard $^{3} S$ were similar and only slightly lower than non-amended switchgrass. By 20 WAP, all substrates had similar $\mathrm{pH}$ averaging 6.0. After 20 weeks in production, there was less than $\mathrm{l}$ unit change in $\mathrm{pH}$ for the three switchgrass substrates. Similar to Expts. 1 and 2, amendment with both peatmoss and MSC buffered $\mathrm{pH}$ against drastic change over the production period of the crop.

SPAD chlorophyll readings were similar across treatments at 12 and 20 WAP (Table 5). There were differences in foliar nutrient content, although most were unremarkable. Across 12 and $20 \mathrm{WAP}$, foliar K, S, $\mathrm{B}$, and Mn were less in some switchgrass substrates compared with pine bark (Table 6), but all treatments were within sufficiency ranges (Mills and Jones, 1996). At $20 \mathrm{WAP}$, foliar $\mathrm{N}$ of plants growing in switchgrass amended with $0.25 \mathrm{lb} /$ yard $^{3} S$ was less than those growing in pine bark. Foliar Fe was the most deficient nutrient in switchgrass substrates. Despite amendment with $1.5 \mathrm{lb} /$ yard $^{3}$ micronutrient package containing $17 \% \mathrm{Fe}$ by weight (from ferrous sulfate), Fe levels in plants growing in switchgrass 20 WAP were consistently lower than those growing in pine bark and at or below the sufficiency range for blueberries. Considering the similarity in $\mathrm{pH}$ levels between pine bark and switchgrass substrates in this experiment, it is unlikely that substrate $\mathrm{pH}$ is the cause of the observed Fe deficiency. Pine bark alone has been shown to be an excellent source of micronutrients in

Table 6. Foliar nutrient concentration in foliage of blueberry grown in pine bark and switchgrass substrates amended with 0 , 0.25 , or $0.5 \mathrm{lb} / \operatorname{yard}^{3}\left(0,0.148\right.$, or $0.297 \mathrm{~kg} \cdot \mathrm{m}^{-3}$, respectively) elemental S.

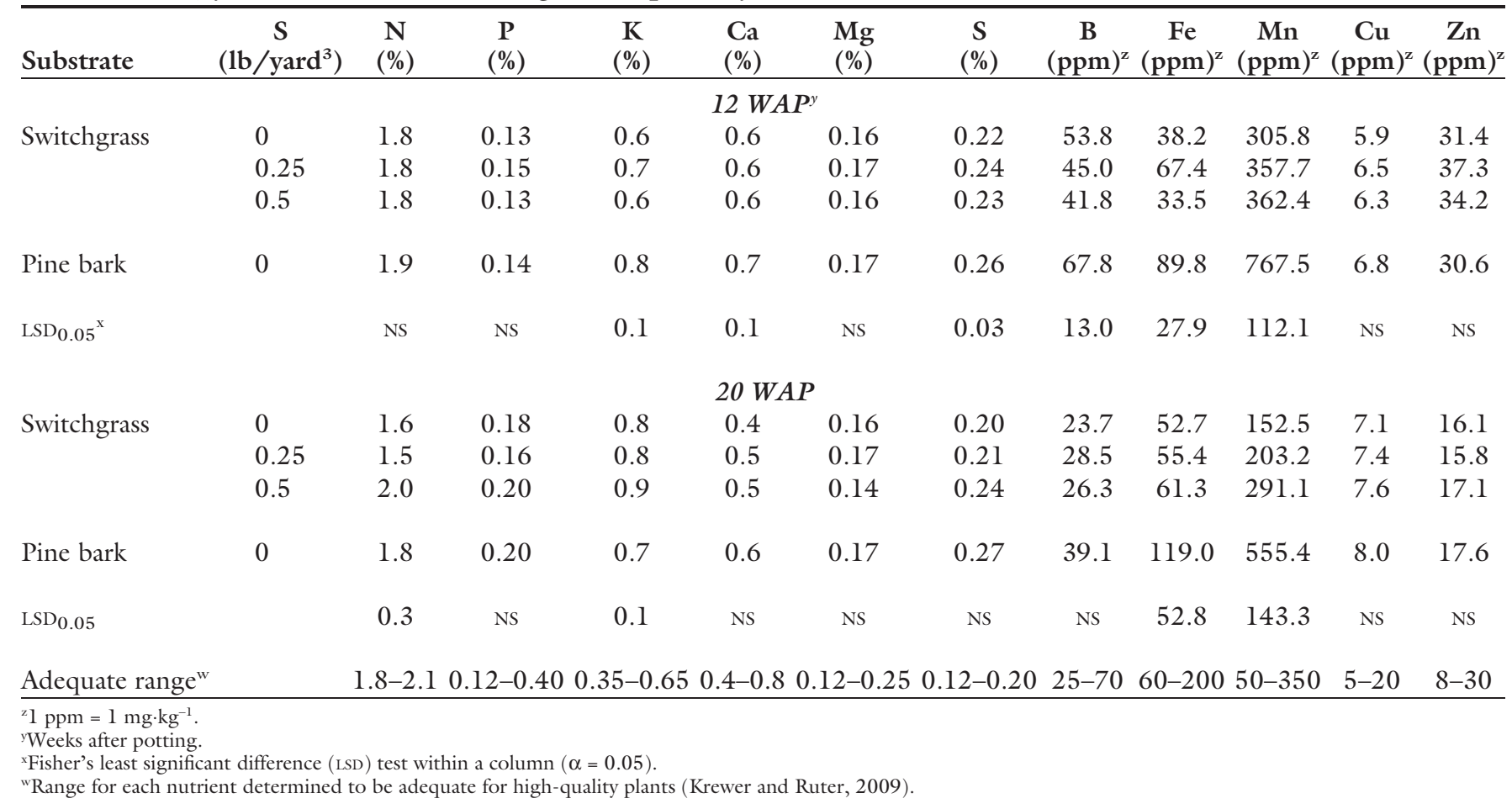


the production of ornamental crops in containers (Niemiera, 1992; Rose and Wang, 1999). Switchgrass substrates will need to be further developed to avoid Fe deficiencies.

At 12 WAP, blueberries grown in pine bark substrate were $\approx 27 \%$ larger than those growing in switchgrass substrate amended with either 0 or $0.5 \mathrm{lb} /$ yard $^{3} S$ (Table 5). By $20 \mathrm{WAP}$, there were no differences in blueberry SDW. We have observed in other research (data not published) that plants growing in switchgrass substrates initially grow more slowly than those in pine bark substrates, but after 6 to 8 weeks, plants in switchgrass substrates will have grown similar to or larger than plants in pine bark substrates. Root ratings for blueberries were similar at 12 and 20 WAP. Giblin and Gillman (2006) showed that rates from 1.5 to $4.5 \mathrm{lb} /$ yard $^{3} \mathrm{~S}$ did not affect 'Northcountry' blueberry root or shoot growth compared with nonamended controls.

In summary, peatmoss and MSC improved the physical properties of switchgrass substrates by decreasing AS and increasing CC. Peatmoss and MSC also decreased substrate $\mathrm{pH}$ of switchgrass to a level more conducive to annual vinca production. Elemental $\mathrm{S}$ was effective at reducing $\mathrm{pH}$, but rates should be limited to less than 1 $\mathrm{lb} /$ yard $^{3}$ and varied depending on the species being grown and its $\mathrm{pH}$ requirement. Combinations of peatmoss and MSC were more effective in buffering $\mathrm{pH}$ against changes than either component alone. It is possible that the combination of peatmoss and
MSC was most effective in buffering $\mathrm{pH}$ because of an additive effect from their chemical properties, or because addition of both components reduced the percent volume of switchgrass lower than either component alone. Plant growth and quality, in terms of SPAD readings and SDW, were improved with additions of peatmoss and MSC but negatively affected with higher rates of elemental $\mathrm{S}\left(>\mathrm{l} \mathrm{lb} / \mathrm{yard}^{3}\right)$. When using switchgrass substrates, addition of up to $20 \%$ peatmoss and $10 \%$ MSC is recommended for improving physical properties, moderating and buffering $\mathrm{pH}$, and improving crop growth. Nursery growers in Ohio already amend pine bark with $\approx 20 \%$ peatmoss and $\approx 10 \%$ MSC; thus, this aspect of substrate management would not be affected if growers changed to switchgrass-based substrates.

\section{Literature cited}

Altland, J.E., C.H. Gilliam, J.H. Edwards, G.J. Keever, D.C. Fare, and J.L. Sibley. 2002. Rapid determination of nitrogen status in annual vinca. J. Environ. Hort. 20: 189-194.

Altland, J.E. and C. Krause. 2009. Use of switchgrass as a nursery container substrate. HortScience 44:1861-1865.

Bishko, A.J. and P.R. Fisher. 2003. The $\mathrm{pH}$-response of a peat-based medium to application of acid-reaction chemicals. HortScience 38:26-31.

Fonteno, W.C. and T.E. Bilderback. 1993. Impact of hydrogel on physical properties of coarse-structured horticul- tural substrates. J. Amer. Soc. Hort. Sci. 118:217-222.

Giblin, C.P. and J.H. Gillman. 2006. Substrate $\mathrm{pH}$ suppression using incorporated sulfur-based compounds in nursery container production. J. Environ. Hort. 24:119-123.

Kessler, J.R. 1998. Greenhouse production of annual vinca. Ala. Coop. Ext. Syst. Publ. ANR-1119.

Krewer, G. and J. Ruter. 2009. Fertilizing highbush blueberries in pine bark beds. The Univ. of Georgia Coop. Ext. Bul. 1291.

Mills, H.A. and J.B. Jones. 1996. Plant analysis handbook II. MicroMacro Publishing, Athens, GA.

Niemiera, A.X. 1992. Micronutrient supply from pine bark and micronutrient fertilizers. HortScience 27:272.

Ownley, B.H., D.M. Benson, and T.E. Bilderback. 1990. Physical properties of container substrate and relation to severity of phytophthora root rot of rhododendron. J. Amer. Soc. Hort. Sci. 115:564570 .

Rathier, T.M. 1983. A comparison of sulfur sources for lowering container media pH. Amer. Nurseryman 157(1):105107.

Rose, M.A. and H. Wang. 1999. Comparison of micronutrient sources for container rhododendron. Hort Technology 12: 220-224.

Yeager, T.H., C.H. Gilliam, T.E. Bilderback, D.C. Fare, A.X. Niemiera, and K.M. Tilt. 2007. Best management practices: Guide for producing nursery crops. South. Nursery Assn., Atlanta, GA. 